\title{
Health Properties and Composition of Honeysuckle Berry Lonicera caerulea L. An Update on Recent Studies
}

\author{
Marta Gołba *(D), Anna Sokół-Łętowska ${ }^{\mathbb{D}}$ and Alicja Z. Kucharska \\ Department of Fruit, Vegetable and Plant Nutraceutical Technology, Wrocław University of Environmental and \\ Life Sciences, Chełmońskiego 37, 51-630 Wrocław, Poland; anna.sokol-letowska@upwr.edu.pl (A.S.Ł.); \\ alicja.kucharska@upwr.edu.pl (A.Z.K.) \\ * Correspondence: marta.golba@upwr.edu.pl \\ Academic Editor: Francesco Cacciola \\ Received: 7 December 2019; Accepted: 6 February 2020; Published: 9 February 2020

\begin{abstract}
Lonicera caerulea L., also known as haskap or honeysuckle berry, is a fruit commonly planted in eastern Europe, Canada and Asia. The fruit was registered as a traditional food from a third country under European Union regulations only on December 2018. It is resistant to cold, pests, various soil acidities and diseases. However, its attractiveness is associated mostly with its health properties. The fruit shows anticancer, anti-inflammatory, and antioxidant activity-important factors in improving health. These features result from the diverse content of phytochemicals in honeysuckle berries with high concentrations of phytocompounds, mainly hydroxycinnamic acids, hydroxybenzoic acids, flavanols, flavones, isoflavones, flavonols, flavanones and anthocyanins but also iridoids, present in the fruit in exceptional amounts. The content and health properties of the fruit were identified to be dependent on cultivar, genotype and the place of harvesting. Great potential benefits of this nutritious food are its ability to minimize the negative effects of UV radiation, diabetes mellitus and neurodegenerative diseases, and to exert hepato- and cardioprotective activity.
\end{abstract}

Keywords: Lonicera caerulea; polyphenols; iridoids; anthocyanins; biological activity

\section{Introduction}

Lonicera caerulea L. is a plant well-known in eastern countries, particularly in China and Russia [1]. It is commonly known as haskap berry (referred to Japanese blue honeysuckle type) or honeyberry (Russian and Kuril varieties of blue honeysuckle) [2], and to avoid redundancy, the name "honeysuckle" will be used further in the text to describe all varieties. The plant naturally occurs in forests in Europe, North Asia and North America, mostly in mountainous and low-lying wet regions [3]. Japanese Ainu aborigines have considered honeysuckle berries as an "elixir of life", and on Hokkaido Island, a juice made out of the fruit is sold as a "gold remedy for eternal youth and longevity" [2,4]. In recent years, it has been widely planted in Europe-mainly in Poland, Slovenia, the Czech Republic and Slovakia [5] - but it is still gaining in popularity. Figure 1 presents a photograph of the plant. It belongs to the Caprifoliaceae family, and its fruit is known as honeysuckle berries (mostly referring to Japanese blue honeysuckle), also named honeysuckle berries (associated with the commercial name for Russian and Kuril cultivars) [2,6]. The genus Lonicera consists of over 200 cultivars [7]. Currently, the most commonly planted are honeysuckle berries originating in Russia, Japan, Canada and Poland. The cultivars most popular and easiest to grow are tundra, borealis, indigo gem, blue lightning and kamchatka [2]. A great advantage of the fruit is its high resistance to low temperatures. It can survive up to $-40{ }^{\circ} \mathrm{C}$ and the flowers to $-7^{\circ} \mathrm{C}$. Moreover, they are not affected by variations in soil $\mathrm{pH}$, presence of pests or diseases [5]. The berries have an elongated elliptic or cylindrical shape, are dark purple 
in color and a waxy coating can be observed on their surface. Their weight ranges from 0.3 to $2.0 \mathrm{~g}$. They can reach approximately $2 \mathrm{~cm}$ in length and $1 \mathrm{~cm}$ in width [6]. The taste can be characterized as bitter to sour-sweet, varying among cultivars [8].

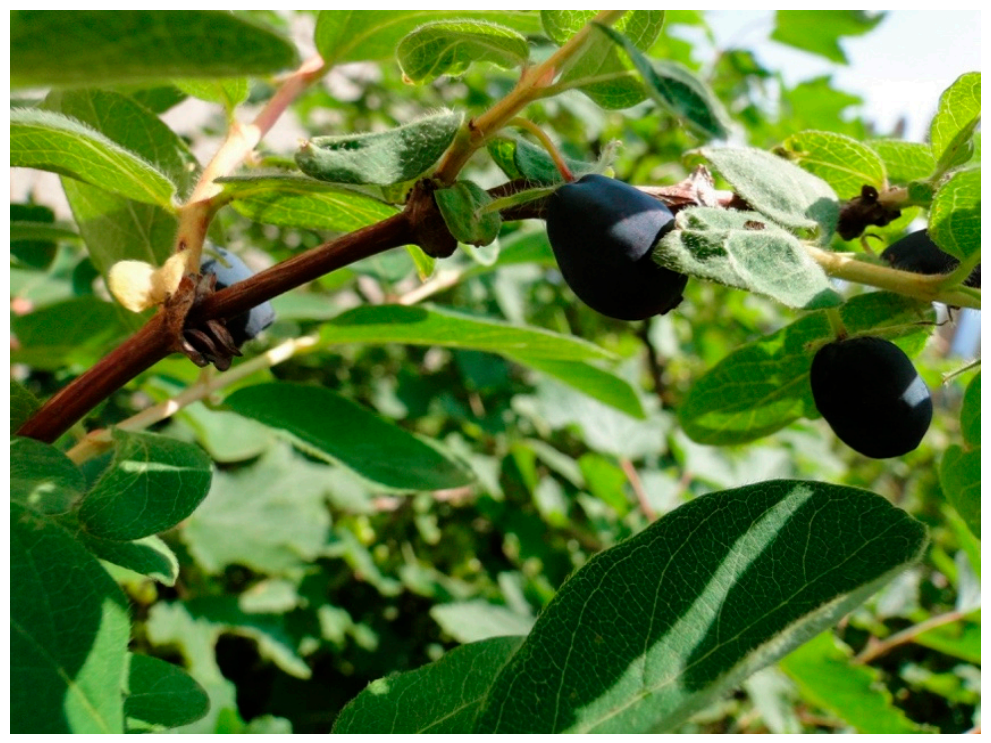

Figure 1. Lonicera caerulea L. with fruit.

The number of studies investigating the properties and content of berries is growing. The aim of this paper is to present the current state of art about the composition, health properties and recent findings regarding the plant.

\section{Acid Composition in Lonicera caerulea L.}

The berries show high content of numerous primary and secondary metabolites [5]. One of them is ascorbic acid, which plays an important role as an antioxidant agent, counteracting harmful processes such as inflammation. Honeysuckle berry is claimed to be one of the richest sources of vitamin $C$ among all the berries. The content can vary based on climate and cultivation conditions, genotype, stage of ripeness and harvesting time [9-11]. The main environmental factors influencing ascorbic acid level are solar radiation, average temperature and precipitation [12]. It was shown that lower temperatures and wet weather have a positive impact on ascorbic acid content [9]. A study conducted by Jurikova et al. [13] proved that ascorbic acid values of certain honeysuckle berry cultivars can even exceed other fruit generally considered as rich in vitamin C. Oranges contain $31 \mathrm{mg} / 100 \mathrm{~g}$ of ascorbic acid, red currants from 35 to $90 \mathrm{mg} / 100 \mathrm{~g}$, black elderberries around $30 \mathrm{mg} / 100 \mathrm{~g}$ and raspberries between 16 to $32 \mathrm{mg} / 100 \mathrm{~g}$ [5], while Lonicera caerulea cultivars show values up to $186 \mathrm{mg} / 100 \mathrm{~g}$ [13]. Another study indicates values ranging from $17 \mathrm{mg} / 100 \mathrm{~g}$ to $25 \mathrm{mg} / 100 \mathrm{~g}$ [3]. In a study performed by Viskelis et al. [14], it was found that berries planted in northern regions have higher levels of the acid than those from southern parts. It has been reported that consumption of vitamin $C$ reduces reactive oxygen species levels, as well as triglyceride content, suggesting anti-inflammatory and anti-atherosclerotic properties [15].

Referring to organic acid composition, it is important to emphasize their importance for sensory quality of the fruit [5]. The amount of organic acids is negatively correlated with light intensity, contrary to the amount of accumulated sugars [16]. It was also reported that organic acid content was negatively correlated with total phenolics, meaning that acids decrease when the phenolic content rises [17]. The most prevalent organic acids found in honeysuckle berries are citric acid, which comprise $62 \%$ of total organic acids, malic acid (30\%), quinic acid (6\%), tartaric acid (1\%), shikimic and fumaric acid [17]. These values correspond to the total organic acid content in honeysuckle berries of 6.55 to 
$8.85 \mathrm{mg} / \mathrm{g}$, and the results are dependent on the fruit cultivation location. Another study presented values ranging from 6.75 to $11.04 \mathrm{mg} / \mathrm{g}$ [5]. The values in other berries exceed all these numbers; for bilberries, the reported amount of organic acid is equal to $1031 \mathrm{mg} / 100 \mathrm{~g}$, blackcurrants contain $2137 \mathrm{mg} / 100 \mathrm{~g}$ and red currants $1805 \mathrm{mg} / 100 \mathrm{~g}$. A study performed in Slovenia initially compared honeysuckle berry composition of the cultivar aurora from different locations and also presented the results of various cultivars from one region. There were found significant differences between the regions, where the highest values reached $8.86 \mathrm{mg} / \mathrm{g}$ and the lowest $6.56 \mathrm{mg} / \mathrm{g}$. The discrepancies between cultivars ranged from $11.04 \mathrm{mg} / \mathrm{g}$ for borealis to $6.75 \mathrm{mg} / \mathrm{g}$ for aurora.

\section{Sugar and Mineral Content}

Fructose comprises more than half (55\%) of total sugars found in honeysuckle berries [5]. Other sugars present in the fruit are glucose $(43 \%)$ and sucrose $(3 \%)$. The fruit is considered to contain less sugar than, for example, blueberries and could be recommended for a diabetic diet. The total sugar content in honeysuckle berries ranges from approximately $15 \mathrm{mg} / \mathrm{g}$ up to $25.85 \mathrm{mg} / \mathrm{g}$ of fresh fruit, while the value for blueberries is $78.1 \mathrm{mg} / \mathrm{g}$, for raspberry $45.5 \mathrm{mg} / \mathrm{g}$ and for red currant $38.2 \mathrm{mg} / \mathrm{g}[5,16,17]$. Higher light exposure and later, harvesting time, positively correlate with sugar content $[18,19]$. One cultivar that is low in sugar is honeybee, containing $15.57 \mathrm{mg} / \mathrm{g}$, while higher levels can be observed in tundra $(17.34 \mathrm{mg} / \mathrm{g})$ and aurora $(25.85 \mathrm{mg} / \mathrm{g})$ [5]. The impact of irrigation on sugar levels was analyzed, but no significant correlation was observed [20].

Considering mineral content, honeysuckle berries contain similar amounts of potassium, calcium and magnesium to wild berries [21]. Potassium is the most prevalent compound found in the berries, followed by phosphorus, magnesium and calcium, while sodium shows the lowest concentration [20]. The content of the mentioned minerals can vary a lot. A study by Plekhanova et al. [22] indicated values ranging between 300 and $500 \mathrm{mg} / \mathrm{kg}$ fresh weight (FW). Another study described potassium levels ranging between 10 and $15 \mathrm{mg} / \mathrm{kg}$ [20], while Sochor et al. [23] reported potassium levels in honeysuckle berries ranging from 3000 to $5000 \mathrm{mg} / \mathrm{kg}$. Species, as well as the year of plant vegetation, was found to be a significant factor corresponding to potassium level in the fruit [20]. Magnesium content shows values between 79 and $163 \mathrm{mg} / \mathrm{kg}$ [23], while the average result in the study by Jurikova and Matuskovic [20] indicated the content of $711 \mathrm{mg} / \mathrm{kg}$. The mean value of phosphorus in the latter study was $2252 \mathrm{mg} / \mathrm{kg}$, while another source reported an average value of $486 \mathrm{mg} / \mathrm{kg}$ [23]. The level of calcium was, on average, $1077 \mathrm{mg} / \mathrm{kg}$ and, for sodium, $81.67 \mathrm{mg} / \mathrm{kg}$ [20], and according to another study, it showed values of $442 \mathrm{mg} / \mathrm{kg}$ and $14 \mathrm{mg} / \mathrm{kg}$ for calcium and sodium, respectively [23]. Lower mineral values may result from discrepancies in cultivation conditions and the impact of climate variation. Minerals play an important role in processes such as nerve impulses transmittance, hormones formation and heartbeat regulation. Moreover, they are also a structural part of numerous enzymes and are also among the key factors responsible for functioning of immune and brain systems [24].

\section{Phytocompound Composition in Lonicera caerulea L. Fruit}

It was reported that honeysuckle berries show the highest level of polyphenolic compounds out of all the berries grown in Canada $[25,26]$. The amount identified in one of the studies $(1111.17 \mathrm{mg} / 100 \mathrm{~g})$, exceeds even the values identified in bilberries $(778.47 \mathrm{mg} / 100 \mathrm{~g})$, wild strawberries $(437.04 \mathrm{mg} / 100 \mathrm{~g}$ ) and purple raspberries $(638.09 \mathrm{mg} / 100 \mathrm{~g})$ [26]. Phenolics exert a great impact on health, and thus, attract a lot of attention and have been a subject of many studies. The total phenolic content (TPC) reaches values from 1.41 to $11.42 \mathrm{mg}$ gallic acid equivalents (GAE) per gram of FW. Studies have shown that honeysuckle berry fruit contains triterpenoic acids, $\beta$-carotene, catechol, flavonols, chlorogenic acid and many more acids [27]. The phenolic compounds can be classified into nine groups: hydroxycinnamic acids, hydroxybenzoic acids, flavanols, flavones, isoflavones, flavonols, flavanones and anthocyanins [5]. Out of all phenolics found in honeysuckle berry fruit, the greatest proportion, ranging between $36 \%$ and $51 \%$, is observed for anthocyanins-peonidin glycosides, cyanidin and petunidin. The main anthocyanin identified was cyanidin 3-O-glucoside [28,29]. The level of anthocyanins is claimed to be 
dependent on harvest time and cultivar [11]. Moreover, it was reported that another factor influencing the anthocyanin level is low temperature [5]. Higher content of anthocyanins could result from low temperatures and solar radiation. It was also observed that overripe berries show higher concentrations of anthocyanins [30,31]. Larger fruits were found to contain more anthocyanins due to the high area of the skin surface, where the compounds mostly accumulate [5]. The second most abundant compounds were phenolic acids (24\%). Phenolic acids can be divided into two classes according to their structure: derivatives of cinnamic acid and benzoic acid [32]. A study by Zadernowski et al. [33] showed that $61.1 \%$ of honeysuckle berry total phenolic acids consisted of hydroxycinnamic acids (mostly chlorogenic acid) and their derivatives ( $p$-coumaric acid and $m$-coumaric acid). Another study reported the abundance of rosmarinic, vanillic and gentisic acids, with values of $0.08 \%$ in total [34]. Flavonols-kaempferol, isorhamnetin glycosides and quercetin - correspond to $22 \%$ of total phenolics. Quercetin 3-O-rutinoside showed the highest contribution to total flavonols. Similar to anthocyanin content, flavonol levels are also positively correlated with higher altitudes. A study by Albert et al. [35] indicated an increase of flavonol concentration with declining temperature. Similar to the content of anthocyanins, the level of chlorogenic acid and derivatives depends on cultivation localization and the cultivar [36]. It was also reported that hydroxycinnamic acid levels positively correlate with higher altitude, being associated with a response to stronger UV radiation observed there $[5,17,37]$. A strong negative correlation was observed between the weight of the fruit and total hydroxycinnamic acids, hydroxybenzoic acids, flavanones and flavanols [5]. The total phenolic content is negatively correlated with organic acids but shows a positive correlation with sugars. Flavanols were one of the least prevalent substances found in honeysuckle berry ( $11 \%$ of total phenolics). Their content is also UV radiation-dependent. Flavanols consisting of (-)-epicatechin, (+)-catechin and procyanidin oligomers can be found mostly in small, nonmature fruit, and their content shows no correlation with temperature or altitude. However, a strong correlation with fruit weight can be observed. Another potential influencing factor is exposure to light. Flavones which are also present in honeysuckle berry fruit include luteolin glycosides, which show increased levels with the time of harvesting [11]. According to the literature, a long-term consumption of polyphenol-rich products protects against cardiovascular diseases, osteoporosis, lung damage, certain types of cancers, type 2 diabetes, gastrointestinal disorders and neurodegenerative diseases [38].

A comparison of total phenolics was carried out by Ochmian et al. [11], who investigated the impact of harvesting time on the fruit. The results showed that, in both analyzed cultivars, the total phenolic content was higher at the end of the harvesting time. In this study, anthocyanins were clearly dominating compounds, with the major constituent being cyanidin 3-O-glucoside. In the research of Senica et al. [5], four cultivars and their phenolic contents were compared. The highest total phenolic content was reported in tundra, with $268.22 \mathrm{mg} / 100 \mathrm{~g}$, followed by honey bee, with $225.30 \mathrm{mg} / 100 \mathrm{~g}$. A slightly lower value was recorded in the cultivar aurora, with $219.64 \mathrm{mg} / 100 \mathrm{~g}$, and the lowest content was observed in borealis, with $173.51 \mathrm{mg} / 100 \mathrm{~g}$. The same research also emphasized the presence of saponins. This compound is mostly present in exotic fruits such as papaya, honey locus and dragon fruit, but it was also found in honeysuckle berries. Its level was reported to be positively correlated with ascorbic acid. The highest saponin content out of all cultivars analyzed in the study was shown by honey bee, with $640.79 \mathrm{mg}$ of diosgenin equivalents/100 g.

Tannins are another group of compounds found in honeysuckle berries. They are related to astringent taste and are present in high concentrations in pomegranate peel $(29,223 \mathrm{mg}$ GAE/100 g) and persimmon (1010 mg GAE/ $100 \mathrm{~g})$. The study of Senica [5] identified tannin content in the berries to range from $129.81 \mathrm{mg} \mathrm{GAE} / 100 \mathrm{~g}$ to only trace amounts, depending on the cultivar. It is also worth emphasizing the presence of iridoids, which are not commonly found in fruits. They belong to a group of monoterpenoids; in terms of structure, they are cyclopentan-[C]-pyran monoterpenoids, and they provide a link between alkaloids and terpenes [39,40]. They are responsible for the bitter taste in fruit and possess a wide range of antioxidant and anti-inflammatory properties [37,41]. In a study by Kucharska et al. [42], there were fifteen iridoids identified. The research reported that even though the 27 cultivars which were analyzed show 
similar content of most phenolic compounds, the profile of iridoids varies significantly, ranging from the minimal amount of $119.95 \mathrm{mg} / 100 \mathrm{~g}$ of FW in the cultivar dlinnoplodnaya, to maximally $276.43 \mathrm{mg} / 100 \mathrm{~g}$ of FW identified in the berry smart blue cultivar. In general, the high level of phytocompounds and diverse composition correspond to high nutraceutical values and a high health potential of honeysuckle berries.

\section{Antioxidant Activity}

High antioxidant activity has become a topic of numerous studies. Consumption of products containing high levels of antioxidants shows a positive effect on counteracting cancer tumor and inflammatory diseases [43]. It was identified that honeysuckle berry serves as a rich source of free radical scavengers. According to the study by Halvorsen et al. [44], blackberries, strawberries, raspberries, cranberries and blueberries are among the top antioxidant foods. Rupasinghe et al. [25] in an in vitro test proved that honeysuckle berries show higher activity than commonly eaten strawberries or blackberries. According to the result of FRAP (ferric reducing antioxidant power) analysis, the antioxidant capacity of cultivar borealis is equal to $46.38 \mathrm{mg} \mathrm{GAE} / 100 \mathrm{~g}$ FW, while the value for strawberries is $8.00 \mathrm{mg} \mathrm{GAE} / 100 \mathrm{~g}$ FW and for blackberries $15.03 \mathrm{mg}$ GAE/100 g FW. The activity can vary based mainly on the cultivar and genotype, which could influence the content quality and quantity [42]. Among the most antioxidative compounds of berries are vitamin $\mathrm{C}$ and polyphenols, mainly anthocyanins, phenolic acids, flavonols and flavanols $[45,46]$. Rop et al. [47] found that the antioxidant activity can vary significantly among species. The highest values out of twelve analyzed cultivars were identified in Zolushka and Gerda (10.17 and $9.92 \mathrm{~g}$ of ascorbic acid equivalent (AAE)/ $\mathrm{kg}$ fresh mass, respectively), while the lowest levels were observed in leningradskii velikan and nimfa (6.59 and $6.75 \mathrm{~g}$ of AAE/kg FW, respectively). The results are consistent with those obtained by Sochor et al. [23], who also examined similar cultivars. Their study showed the zolushka cultivar to be the best antioxidant and to contain the most phenolic compounds. Compared to other commonly consumed fruits, these values are considerably high. The results of antioxidant activity of cherries reach a maximum value of $0.9 \mathrm{~g}$ of AAE $/ \mathrm{kg}$ FW, while, for plums, it is up to $6 \mathrm{~g}$ of AAE/kg FW [47,48]. Rupasinghe et al. [25] took into account other cultivars, and they observed the highest antioxidant capacity in borealis, indigo gem and tundra. Borealis showed the strongest activity, as well as having the highest total phenolic and total flavonoid contents determined by spectrophotometric methods. Cultivars amur and jolanta were reported to be among other strong antioxidative agents [42]. Less active ones include atut and karina. There was also reported a strong correlation between antioxidant power and anthocyanins. In contrast, the amount of iridoids is weakly correlated with antioxidant capacity. This discrepancy can be explained by the presence of OH groups, which are able to reduce free radicals [49]. Therefore, iridoids could serve more as an anti-inflammatory or antibacterial agent, which gives honeysuckle berries even wider health properties. Moreover, a study by Zhao et al. [50] revealed that the antioxidant activity depends on the way of bioactive compounds' extraction. According to the study, methanol extracts show higher antioxidant activities than those obtained with ethyl acetate or dichloromethane. An in vivo study reported that phenolic extracts from honeysuckle berry increased levels of reduced glutathione strictly connected with antioxidant activity [51]. A summary of total content of polyphenols, anthocyanins, flavanols, phenolic acids and iridoids in 19 cultivars, obtained from various studies, is presented in Table 1. All the conducted research has confirmed the high antioxidant activity of honeysuckle berries, depending mostly on the cultivar and, thus, the content of bioactive compounds. 
Table 1. Different polyphenol contents in analyzed cultivars of honeysuckle berry (ND—no data and FW—fresh weight).

\begin{tabular}{|c|c|c|c|c|c|c|}
\hline Cultivar & $\begin{array}{c}\text { Total } \\
\text { Polyphenols } \\
\text { (mg gallic } \\
\text { acid/100 g } \\
\text { FW) }\end{array}$ & $\begin{array}{c}\text { Total } \\
\text { Anthocyanins } \\
(\mathrm{mg} / 100 \mathrm{~g} \text { FW) }\end{array}$ & $\begin{array}{c}\text { Total } \\
\text { Flavanols } \\
(\mathrm{mg} / 100 \mathrm{~g} \\
\text { FW) }\end{array}$ & $\begin{array}{c}\text { Total } \\
\text { Phenolic } \\
\text { Acids } \\
\text { (mg/100 g } \\
\text { FW) }\end{array}$ & $\begin{array}{c}\text { Total } \\
\text { Iridoids } \\
(\mathrm{mg} / 100 \mathrm{~g} \\
\text { FW) }\end{array}$ & References \\
\hline Amfora & $563.2 \pm 9.4^{1}$ & 471.3 & 26.3 & 48.0 & 232.0 & {$[4,23]$} \\
\hline Amur & $732.6 \pm 11.1$ & 655.2 & 28.7 & 62.4 & 259.9 & {$[4,23]$} \\
\hline Aurora & $219.6 \pm 19.2$ & $112.37 \pm 6.7$ & $8.15 \pm 4.3$ & $20.5 \pm 9.7$ & $0.5 \pm 0.1$ & [5] \\
\hline Borealis & $173.5 \pm 17.5$ & $86.0 \pm 7.0$ & $19.4 \pm 1.4$ & $38.7 \pm 4.3$ & $0.3 \pm 0.1$ & [5] \\
\hline Fialka & $659.6 \pm 7.1$ & 432.5 & 21.1 & 79.1 & 208.7 & {$[4,23,47]$} \\
\hline Gerda & $823.6 \pm 10.5$ & ND & ND & ND & ND & {$[23,47]$} \\
\hline $\begin{array}{l}\text { Goluboje } \\
\text { vreteno }\end{array}$ & $865.9 \pm 10.9$ & 273.8 & 36.1 & 65.2 & 197.5 & {$[4,23,47]$} \\
\hline Honey Bee & $225.3 \pm 19.3$ & $86.3 \pm 8.1$ & $24.2 \pm 3.5$ & $51.7 \pm 7.8$ & $0.3 \pm 0.1$ & [5] \\
\hline Kamchadalka & $779.8 \pm 8.8$ & 224.6 & 31.3 & 91.0 & 203.6 & {$[4,23]$} \\
\hline $\begin{array}{l}\text { Leningradskij } \\
\text { velikan }\end{array}$ & $623.5 \pm 8.8$ & 220.3 & 24.6 & 61.0 & 217.6 & {$[4,23,47]$} \\
\hline Morena & $623.5 \pm 7.7$ & 473.7 & 24.6 & 65.6 & 272.6 & {$[4,23,47]$} \\
\hline Nimfa & $625.9 \pm 5.4$ & 557.7 & 18.3 & 62.2 & 158.5 & {$[4,23,47]$} \\
\hline Roksana & $789.6 \pm 10.3$ & 197.3 & 39.2 & 71.1 & 150.0 & {$[4,23,47]$} \\
\hline Sinogalaska & $778.9 \pm 12.4$ & 306.3 & 47.7 & 76.8 & 122.7 & {$[4,23]$} \\
\hline Vasilevskaya & $698.5 \pm 13.2$ & 224.8 & 50.7 & 85.3 & 177.9 & {$[4,23,47]$} \\
\hline Viola & $715.9 \pm 8.4$ & 151.7 & 32.6 & 59.0 & 150.3 & {$[4,23,47]$} \\
\hline Tomichka & $825.9 \pm 12.9$ & 195.5 & 28.4 & 115.5 & 125.1 & {$[4,23,47]$} \\
\hline Tundra & $268.2 \pm 3.5$ & $112.5 \pm 2.4$ & $24.0 \pm 1.1$ & $68.1 \pm 2.4$ & $0.4 \pm 0.1$ & [5] \\
\hline Zoloushka & $856.9 \pm 11.5$ & ND & ND & ND & ND & {$[23,47]$} \\
\hline
\end{tabular}

${ }^{1}$ Data are presented as mean value \pm standard deviation $(\mathrm{SD})$.

\section{Other Health Properties}

The plant is commonly used in traditional medicine, especially in Japan, being exceptional due to its anti-ageing properties, as well as protecting against heart diseases and gastrointestinal problems [1]. Scientific studies have confirmed cardio- and neuroprotective, anticancer and anti-inflammatory activity of the honeysuckle fruit [52]. Moreover, antimicrobial and antidiabetic properties have been observed. The mentioned features are mostly connected to bioactive compounds present in the berries, mainly phenolic compounds including anthocyanins, chlorogenic acid and quercetin [42]. The presence of iridoids in honeysuckle berries also corresponds to its attractiveness, as they are not commonly found in fruit. Apart from honeysuckle, the compounds can only be found in cornelian cherry fruits, bilberry and cranberry. Prevalent antioxidants are able to reduce reactive oxygen species, counteracting aging processes [53]. Moreover, according to conducted studies, regular consumption of berries could reduce cancer and insulin resistance, minimize bone loss and improve neurocognitive functions [54-57]. Studies have also shown the positive impact of honeysuckle berries on inhibiting melanogenesis, resulting in a whitening effect [1].

\subsection{Antimicrobial Properties}

Bacterial tests have identified antimicrobial properties of honeysuckle berries, being particularly efficient against Kocuria rhizophila, Bacillus subtilis and Campylobacter jejuni but without affecting health-positive bacteria, meaning the berries could serve as a probiotic food $[1,58]$. It was also proved that extracts of freeze-dried berries and phenolic extracts can effectively counteract microbial adhesion, and thus, prevent various infections such as mouth and urinary diseases [59]. The extracts reduced adhesion of Staphylococcus epidermidis (zero colony forming units (CFU)); Escherichia coli $\left(4.55 \times 10^{3} \mathrm{CFU}\right.$ when freeze-dried extract was used and $1.45 \times 10^{1} \mathrm{CFU}$ when phenolic extract 
was used); Streptococcus mutans $\left(4.48 \times 10^{1} \mathrm{CFU}\right.$ and $0 \mathrm{CFU}$, respectively) and Enterococcus faecalis $\left(6.9 \times 10^{3} \mathrm{CFU}\right.$ and $4.5 \times 10^{0} \mathrm{CFU}$, respectively), in comparison to the control samples $\left(2.59 \times 10^{3}\right.$, $1.6 \times 10^{4}, 5.44 \times 10^{4}$ and $6.1 \times 10^{4} \mathrm{CFU}$ ) [59].

\subsection{Neuroprotective Activity}

It has been reported that daily intake of polyphenols (prevalent in honeysuckle berries) minimizes risk of dementia, neurodegenerative diseases and stroke mainly through free radical scavenging, activation of survival genes and signaling cascades, transition metal chelation, modification of neuroinflammation and regulation of mitochondrial function [60]. Numerous studies have focused on the impact of blue berries, citrus fruit and green tea on human health. It was proved that blueberry extract is able to significantly improve episodic memory and visuospatial working memory as a result of three-months supplementation and can also reduce systolic blood pressure level already after three-months supplementation [61]. A recent study by Bell and Williams [62] demonstrated a significant positive influence of honeysuckle berry extract on physiological and cognitive functions in the immediate postprandial period. A $400 \mathrm{mg}$ dose could lower diastolic blood pressure and heart rate already after $1.5 \mathrm{~h}$ after administration. This observation was related to already examined properties of the vasodilatory and glucoregulatory impact of anthocyanins $[63,64]$. The mentioned physiological changes can be associated with increased cognitive function achieved through increased blood flow to the brain and higher glucose uptake to the brain. Administration of a $400 \mathrm{mg}$ high dose of honeysuckle extract resulted in improvement of episodic memory. It was also suggested that lower doses of $100 \mathrm{mg}$ are not sufficient to affect episodic memory. A limited impact of the extracts on working memory or executive function was reported. Based on all the study findings, honeysuckle berries have a great potential in terms of age-related memory deficits and are able to improve metabolic and vascular health.

\subsection{Hepatoprotective, Cardioprotective and Radioprotective Effect}

A cell culture test indicated that phenolic extracts from honeysuckle berries are able to inhibit liver microsome peroxidation and slow down low-density lipoprotein (LDL) oxidation [59]. This is a crucial factor in minimizing cardiovascular diseases such as atherosclerosis [65]. Tests conducted on mice revealed that phenolic extract of berries can minimize destructive effects of UV radiation-DNA breakage, keratinocytes and membrane damage [51]. Therefore, honeysuckle fruit can also serve as a potential radioprotective agent. A study also identified lower caspase- 3 and caspase- 9 activity, which are associated with reversing cellular apoptosis [66]. Moreover, research has shown that honeysuckle berry extracts protect DNA from damage, thus preventing carcinogenesis [53]. It has also been proved that cancer cells tend to enter apoptosis upon exposure to the berry extract [25].

\subsection{Antidiabetic Properties}

Diabetes mellitus (DM) is also a disease closely associated with a negative impact of free radicals. It is becoming more and more prevalent, with 451 million people affected worldwide in 2017, and it is estimated that 693 million individuals will be affected by 2045 [67]. It has been considered a health pandemic issue resulting in a high mortality rate and numerous complications [68]. Therefore, there is a high demand to find a minimally invasive treatment. A study by Sharma et al. [69] analyzed mice on a high-fat diet (HFD), which showed increased insulin, blood glucose, glycated hemoglobin (HbA1c), blood urea nitrogen (BUN) and creatinine levels. The mice also showed more degenerative lesions and a higher number of pancreas islet cells responsible for insulin/glucagon production. When mice were fed with honeysuckle berry extracts, the mentioned complications were significantly inhibited. Moreover, feeding with $400 \mathrm{mg} / \mathrm{kg}$ extracts resulted in inhibition of type II diabetes and other positive effects, contrary to HFD mice. The fruit was also considered to be a promising treatment for diabetic nephropathies. The study also confirmed dose-dependent activity of honeysuckle berries, which reveals a potential to be a medicinal food for diabetes treatment. 


\subsection{Anti-Inflammatory Properties}

Free radicals' activity can lead to inflammation, cancer and diabetes [70,71]. Moreover, chronic inflammation can cause metabolic diseases, which currently are a very common disorder [72]. Inflammatory pathways are mediated by different factors and enzymes, such as tumor necrosis factor (TNF- $\alpha)$, interferon-gamma (IFN- $\gamma$ ) and cyclooxygenase (COX-2). A healthy diet is one of a few agents influencing metabolic syndrome [73]. Therefore, there is a strong demand for natural plant-derived nutraceuticals aimed at counteracting the disease. Rich in polyphenols, honeysuckle berry shows a potential to scavenge free radicals and also demonstrated a potential to modify the TNF. A study by Rupasinghe et al. [74] presented a negative correlation between polyphenol content of honeysuckle extracts and proinflammatory cytokines COX-2, TNF- $\alpha$, interleukin-6 (IL-6) and prostaglandin $\left(\mathrm{PGE}_{2}\right)$. Inhibition of the inflammatory process was shown to be mostly effective at the start of the signaling cascade; thus, it can be assumed that honeysuckle berry extracts are more efficient in preventing the inflammation rather than treatment. When fibroblast cells were incubated with fruit extracts, a decrease in reactive oxygen species was observed, as well as release of inflammatory markers [75]. Gut microbiota is closely related to metabolic diseases, and gut dysbiosis is associated with metabolic syndromes, including diabetes [76,77]. A high-fat diet increases the level of endotoxins and increases serum levels of inflammatory cytokines connected with nonalcoholic fatty liver disease (NAFLD). Administration of honeysuckle berry polyphenols decreased both endotoxin and cytokines levels [78]. These results suggest that the berries could have an impact on gut bacteria, and thus, rebalance microecological conditions. NAFLD is also claimed to be associated with a reduced amount of Bacteroidetes [79,80]. Similarly, obese people have a higher Firmicutes/Bacteroidetes ratio than people with normal weight. Supplementation with honeysuckle berry-derived polyphenols increased the number of Bacteroidetes and reduced the amount of Firmicutes, resulting in a lower Firmicutes/Bacteroidetes ratio, which was observed to be dose-dependent [78].

Another very important aspect is the ability of honeysuckle berry to decrease eye inflammation, proved on rat models with uveitis [81]. Another group of rats fed with an unbalanced high fructose diet showed a decreased plasma lipid concentration and normalized triglyceride levels after supplementing honeysuckle extracts [82]. Based on the obtained results, the daily intake of phenolic extract beneficial for health promotion for an adult weighing $70 \mathrm{~kg}$ was calculated to be $0.8 \mathrm{~g}$. Unfortunately, so far, no many in vivo studies have been conducted, so the exact impact on the human organism is not known.

The main reviewed properties and the concentrations of berries used are summarized in Table 2.

Table 2. Health-associated effects of honeysuckle berries based on in vitro and in vivo tests.

\begin{tabular}{|c|c|c|c|c|}
\hline Effect & $\begin{array}{l}\text { Material Used in } \\
\text { the Study }\end{array}$ & Method & Study Outcome & References \\
\hline $\begin{array}{l}\text { Improvement of } \\
\text { physiological and } \\
\text { cognitive functions. }\end{array}$ & $\begin{array}{l}\text { Extract containing } \\
400 \mathrm{mg} \\
\text { anthocyanins }\end{array}$ & $\begin{array}{c}\text { Double-blind, } \\
\text { counterbalance, } \\
\text { crossover intervention } \\
\text { study. }\end{array}$ & $\begin{array}{l}\text { Improvement of episodic } \\
\text { memory and blood } \\
\text { pressure after acute } \\
\text { supplementation with } \\
\text { honeysuckle berry } \\
\text { extract. }\end{array}$ & {$[62]$} \\
\hline $\begin{array}{l}\text { Minimize negative effect } \\
\text { of UV radiation-DNA } \\
\text { breakage, keratinocytes } \\
\text { and membrane damage. }\end{array}$ & $\begin{array}{c}10 \text { and } 25 \mathrm{mg} / \mathrm{L} \\
\text { extract }\end{array}$ & $\begin{array}{l}\text { Solar stimulation for } \\
\text { keratinocytes damage } \\
\text { and impact of pre- and } \\
\text { post-treatment with } \\
\text { phenolic extract. }\end{array}$ & $\begin{array}{l}\text { Suppression of } \\
\text { UVB-caused injury of } \\
\text { keratinocytes and } \\
\text { decrease in reactive } \\
\text { oxygen and nitrogen } \\
\text { species (RONS). }\end{array}$ & {$[66]$} \\
\hline
\end{tabular}


Table 2. Cont.

\begin{tabular}{|c|c|c|c|c|}
\hline Effect & $\begin{array}{l}\text { Material Used in } \\
\text { the Study }\end{array}$ & Method & Study Outcome & References \\
\hline $\begin{array}{l}\text { Lowering plasma lipids } \\
\text { and normalizing } \\
\text { triglyceride levels for a } \\
\text { positive effect on } \\
\text { diabetes. }\end{array}$ & $\begin{array}{l}\text { Extract containing } \\
327 \mathrm{mg} \\
\text { anthocyanins/g }\end{array}$ & $\begin{array}{l}\text { Mice on cornstarch or } \\
\text { high-fructose diet, with } \\
\text { and without addition of } \\
\text { honeysuckle berry } \\
\text { extract. }\end{array}$ & $\begin{array}{l}\text { Extract supplemented to } \\
\text { an unbalanced diet } \\
\text { ameliorated the } \\
\text { disturbances in glucose } \\
\text { and lipid metabolism. }\end{array}$ & {$[82]$} \\
\hline $\begin{array}{l}\text { Minimizing nonalcoholic } \\
\text { fatty liver disease } \\
\text { (NAFLD) and balancing } \\
\text { gut microbiota dysbiosis. }\end{array}$ & $250 \mathrm{~g} / \mathrm{L}$ extract & $\begin{array}{c}\text { Mice on high-fat diet fed } \\
\text { with honeysuckle } \\
\text { extract. }\end{array}$ & $\begin{array}{c}\text { Attenuation of } \\
\text { inflammation in NAFLD } \\
\text { through modulation of } \\
\text { gut microbiota. }\end{array}$ & {$[78]$} \\
\hline $\begin{array}{l}\text { Improve hepatic } \\
\text { steatosis and insulin } \\
\text { resistance. }\end{array}$ & $250 \mathrm{~g} / \mathrm{L}$ extract & $\begin{array}{c}\text { Mice on high-fat diet } \\
\text { containing honeysuckle } \\
\text { berry extract. }\end{array}$ & $\begin{array}{l}\text { Suppression of induced } \\
\text { obesity and fat } \\
\text { deposition, increased } \\
\text { insulin sensitivity and } \\
\text { attenuation of oxidative } \\
\text { stress. }\end{array}$ & {$[80]$} \\
\hline $\begin{array}{c}\text { Decreasing insulin, } \\
\text { blood glucose, glycated } \\
\text { hemoglobin (HbA1c), } \\
\text { blood urea nitrogen } \\
\text { (BUN), creatinine level, } \\
\text { inhibition of type II } \\
\text { diabetes andpotential } \\
\text { treatment of diabetic } \\
\text { nephropathies. }\end{array}$ & $\begin{array}{l}400 \mathrm{mg} / \mathrm{kg} \text { body } \\
\text { mass extract }\end{array}$ & $\begin{array}{l}\text { High-fat diet-induced } \\
\text { mild diabetic mice } \\
\text { administered with } \\
\text { honeysuckle berry } \\
\text { extract for } 12 \text { weeks. }\end{array}$ & $\begin{array}{c}\text { Ameliorated diabetic } \\
\text { and related } \\
\text { complications in a } \\
\text { dose-dependent manner. }\end{array}$ & {$[69]$} \\
\hline $\begin{array}{l}\text { Anti-inflammatory } \\
\text { properties. }\end{array}$ & $200 \mathrm{~g} / \mathrm{L}$ extract & $\begin{array}{c}\text { Human monocytes } \\
\text { (THP-1) differentiated } \\
\text { macrophages incubated } \\
\text { with extracts. }\end{array}$ & $\begin{array}{c}\text { Negative correlations } \\
\text { between polyphenol } \\
\text { concentration and } \\
\text { proinflammatory } \\
\text { cytokines. }\end{array}$ & {$[74]$} \\
\hline $\begin{array}{l}\text { Inhibition of liver } \\
\text { microsome peroxidation } \\
\text { and slowing down } \\
\text { low-density lipoprotein } \\
\text { (LDL) oxidation. }\end{array}$ & $\begin{array}{l}\text { Phenolic extract of } \\
18.5 \% \text { anthocyanins }\end{array}$ & $\begin{array}{l}\text { Rat hepatocytes } \\
\text { incubated with extract. }\end{array}$ & Prevention of oxidation. & {$[83]$} \\
\hline Antimicrobial properties. & ND & $\begin{array}{l}\text { Candida parapsilosis, } \\
\text { Staphylococcus } \\
\text { epidermidis, Escherichia } \\
\text { coli, Enterococcus faecalis } \\
\text { and Streptococcus mutans } \\
\text { exposed to extracts. }\end{array}$ & $\begin{array}{l}\text { Superoxide scavenging } \\
\text { activity and suppression } \\
\text { of biofilm formation. }\end{array}$ & {$[59]$} \\
\hline
\end{tabular}

\section{Food Products}

Today, the products available on the market containing honeysuckle fruit are mostly jams, wines, candies, jellies, gelatin, ice cream and yoghurt [84]. A crucial advantage of honeysuckle juice is that its color is stable through time [7]. A promising solution to incorporate honeysuckle berries into a daily diet is using encapsulation techniques and creating value-added products [1]. The mentioned form would provide highly concentrated functional products of controlled substance release, high extract stability and the ability to target desired organs. There is still a strong need to develop such products. A breakthrough in terms of popularization of the honeysuckle berry occurred in 2018. The fruit was registered as a traditional food from a third country under European Union regulations on December 2018 [85]. A recent study by Senica et al. [86] compared different forms of honeysuckle berry products: infusion, juice, spread and smoothie. A spread made out of the fruit showed the highest content of ascorbic acid and phenolic compounds- $-302.02 \mathrm{mg} / 100 \mathrm{~g}$ of dry weight and $1753.54 \mathrm{mg} / 100 \mathrm{~g}$, respectively. High values were also observed for the liqueur and smoothie, while in the infusion (fruit tea) and juice, the content of ascorbic acid was only 119.17 and $118.17 \mathrm{mg} / 100 \mathrm{~g}$, respectively, and the phenolic content 
was 1138.75 and $1108.25 \mathrm{mg} / 100 \mathrm{~g}$, respectively. All the mentioned products had a low sugar content and, therefore, can be served to diabetic patients.

\section{Conclusions}

Lonicera caerulea L. shows high health potential and is a promising source of numerous bioactive compounds, mainly anthocyanins, phenolic acids and flavonols. A unique feature of honeysuckle berries is the presence of iridoids, which are a great anti-inflammatory and antioxidant agent. The rich content of berries corresponds to numerous health benefits. Both in vitro and in vivo studies confirm efficient free radical scavenging of honeysuckle extracts. Reduction of reactive oxygen species is the main reason for properties such as antitumor activity, minimizing insulin resistance and neurocognition improvement. Recent studies emphasize the positive impact on the prevention of diabetes mellitus and decreasing the negative effects. Analysis of the exact content and mechanism of action of the extracts has attracted the attention of many researchers. Therefore, it has been confirmed that a daily intake of honeysuckle berries is able to improve physiological and cognitive functions. Developing honeysuckle-based products, a valuable source of health-promoting compounds which could serve as nutraceuticals, is an important aspect of current research. Definitely, the knowledge about the fruit is broadening, and it is worth continuously updating the topic.

Author Contributions: M.G. reviewed appropriate literature. M.G., A.S.E. and A.Z.K. conceived and wrote the manuscript. All authors have read and agreed to the published version of the manuscript.

Funding: This research received no external funding.

Conflicts of Interest: The authors declare no conflicts of interest.

\section{References}

1. Celli, G.B.; Ghanem, A.; Brooks, M.S.L. Haskap berries (Lonicera caerulea L.)-A critical review of antioxidant capacity and health-related studies for potential value-added products. Food Bioprocess Tech. 2014, 7, 1541-1554. [CrossRef]

2. Lauritzen, E.; Black, B.; Maughan, T. Honeysuckle (Blue Honeysuckle) in the Garden; Horticulture: Utah State University Extension: Salt Lake City, UT, USA, 2015.

3. Bors, B.; Thomson, J.; Sawchuk, E.; Reimer, P.; Sawatzky, R.; Sander, R.; Kaban, T.; Gerbrandt, E.; Dawson, J. Haskap Breeding and Production; Final Report; Saskatchewan Agriculture: Saskatoon, SK, Canada, 2012; pp. 1-142.

4. Lefol, E.B. Haskap Market Development, the Japanese Opportunity; Feasibility Study; University of Saskatchewan: Saskatoon, SK, Canada, 2007.

5. Senica, M.; Stampar, F.; Mikulic-Petkovsek, M. Blue honeysuckle (Lonicera cearulea L. subs. edulis) berry; a rich source of some nutrients and their differences among four different cultivars. Sci. Hortic. 2018, 238, 215-221. [CrossRef]

6. Auzanneau, N.; Weber, P.; Kosińska-Cagnazzo, A.; Andlauer, W. Bioactive compounds and antioxidant capacity of Lonicera caerulea berries: Comparison of seven cultivars over three harvesting years. J. Food Compos. Anal 2018, 66, 81-89. [CrossRef]

7. Thompson, M.M. Caprifoliaceae. In The Encyclopedia of Fruit E Nuts; Janick, J., Paull, R.E., Eds.; CAB International: London, UK, 2008; pp. 232-236.

8. Hummer, K.E.; Pomper, K.W.; Postman, J.; Graham, C.J.; Stover, E.; Mercure, E.W.; Aradhya, M.; Crisosto, C.H.; Ferguson, L.; Thompson, M.M.; et al. Emerging fruit crops. In Fruit Breeding; Badnes, M.L., Byrne, D.H., Eds.; Springer: New York, NY, USA, 2012; pp. 97-147.

9. Pokorná, T.; Matuškovič, J. Assessment of nutritional value of Lonicera kamtschatica and Lonicera edulis berries using fuzzy clustering method II. Acta Hortic. Regiotecturae 2009, 11, 35-38. Available online: http://agris.fao.org/agris-search/search.do?recordID=SK2009100055 (accessed on 1 February 2020).

10. Jurikova, T.; Matuškovič, J.; Gazdík, Z. Effect of irrigation on intensity of respiration and study of sugar and organic acids content in different development stages of Lonicera Kamtschatica and Lonicera Edulis berries. Hortic. Sci. 2009, 36, 14-20. [CrossRef] 
11. Ochmian, I.D.; Skupien, K.; Grajkowski, J.; Smolik, M.; Ostrowska, K. Chemical composition and physical characteristics of fruits of two cultivars of blue honeysuckle (Lonicera Caerulea L.) in relation to their degree of maturity and harvest date. Not. Bot. Horti. Agrobot. Cluj-Napoca 2012, 40, 155-162. [CrossRef]

12. Zheng, J. Sugars, acids and phenolic compounds in currants and sea buckthorn in relation to the effects of environmental factors. Ph.D. Thesis, University of Turku, Turku, Finland, 2013.

13. Jurikova, T.; Sochor, J.; Rop, O.; Mlček, J.; Balla, Š.; Szekeres, L.; Žitný, R.; Zitka, O.; Adam, V.; Kizek, R. Evaluation of polyphenolic profile and nutritional value of non-traditional fruit species in the Czech Republic-A comparative study. Molecules 2012, 17, 8968-8981. [CrossRef]

14. Viskelis, P.; Bobinaite, R.; Rubinskiene, M.; Sasnauskas, A.; Lanauskas, J. Chemical Composition and Antioxidant Activity of Small Fruits. Horticulture 2012, 75, 75-102.

15. Kim, S.M.; Lim, S.M.; Yoo, J.A.; Woo, M.J.; Cho, K.H. Consumption of High-Dose Vitamin C (1250 Mg per Day) Enhances Functional and Structural Properties of Serum Lipoprotein to Improve Anti-Oxidant, Anti-Atherosclerotic, and Anti-Aging Effects via Regulation of Anti-Inflammatory MicroRNA. Food Funct. 2015, 6, 3604-3612. [CrossRef]

16. Mikulic-Petkovsek, M.; Schmitzer, V.; Slatnar, A.; Stampar, F.; Veberic, R. Composition of Sugars, Organic Acids, and Total Phenolics in 25 Wild or Cultivated Berry Species. J. Food Sci. 2012, 77, C1064-C1070. [CrossRef]

17. Senica, M.; Bavec, M.; Stampar, F.; Mikulic-Petkovsek, M. Blue honeysuckle (Lonicera caerulea subsp. edulis (Turcz. Ex Herder) Hultén.) berries and changes in their ingredients across different locations. J. Sci. Food Agric. 2018, 98, 3333-3342. [CrossRef]

18. Yamaki, S. Metabolism and accumulation of sugars translocated to fruit and their regulation. J. Jpn. Soc. Hort. Sci. 2010, 79, 1-15. [CrossRef]

19. Zorenč, Z.; Veberic, R.; Stampar, F.; Koron, D.; Mikulic-Petkovsek, M. Changes in berry quality of northern highbush blueberry (Vaccinium corymbosum L.) during the harvest season. Turk. J. Agric. For. 2016, 40, 855-864. [CrossRef]

20. Jurikova, T.; Matuškovič, J. The study of irrigation influence on nutritional value of Lonicera kamtschatica-Cultivar Gerda 25 and Lonicera edulis berries under the Nitra conditions during 2001-2003. Hortic. Sci. 2007, 34, 1-6.

21. Kusznierewicz, B.; Piekarska, A.; Mrugalska, B.; Konieczka, P.; Namieśnik, J.; Bartoszek, A. Phenolic composition and antioxidant properties of Polish blue-berried honeysuckle genotypes by HPLC-DAD-MS, HPLC postcolumn derivatization with ABTS or FC, and TLC with DPPH Visualization. J. Agric. Food Chem. 2012, 60, 1755-1763. [CrossRef] [PubMed]

22. Plekhanova, M.N.; Streltsyna, S.A. Fruit chemical composition of Lonicera subsect. caerulea (Caprifoliaceae species). In Genetic Resources in Russia and Neighboring Countries; Estonian Agricultural University-Forest Research Institute: Tartu, Estonia, 1998; pp. 143-146.

23. Sochor, J.; Jurikova, T.; Pohanka, M.; Skutkova, H.; Baron, M.; Tomaskova, L.; Balla, S.; Klejdus, B.; Pokluda, R.; Mlcek, J.; et al. Evaluation of antioxidant activity, polyphenolic compounds, amino acids and mineral elements of representative genotypes of Lonicera edulis. Molecules 2014, 19, 6504-6523. [CrossRef]

24. Gharibzahedi, S.M.T.; Jafari, S.M. The importance of minerals in human nutrition: Bioavailability, food fortification, processing effects and nanoencapsulation. Trends Food Sci. Technol. 2017, 62, 119-132. [CrossRef]

25. Rupasinghe, H.P.V.; Yu, L.J.; Bhullar, K.S.; Bors, B. Short Communication: Haskap (Lonicera caerulea): A new berry crop with high antioxidant capacity. Can. J. Plant Sci. 2012, 92, 1311-1317. [CrossRef]

26. Bakowska-Barczak, A.M.; Marianchuk, M.; Kolodziejczyk, P. Survey of bioactive components in Western Canadian berriesThis article is one of a selection of papers published in this special issue (part 2 of 2) on the Safety and Efficacy of Natural Health Products. Can. J. Physiol. Pharmacol. 2007, 85, 1139-1152. [CrossRef]

27. Hedin, P.A.; Phillips, V.A.; Dysart, R.J. Volatile constituents from honeysuckle aphids, Hyadaphis tataricae, and the honeysuckle, Lonicera spp.: Search for assembling pheromones. J. Agric. Food Chem. 1991, 39, 1304-1306. [CrossRef]

28. Oszmiański, J.; Wojdyło, A.; Lachowicz, S.; Gorzelany, J.; Matłok, N. Comparison of bioactive potential of cranberry fruit and fruit-based products versus leaves. J. Funct. Foods 2016, 22, 232-242. [CrossRef]

29. Wojdyło, A.; Nuncio Jáuregui, N.; Carbonell-Barrachina, A.; Oszmiański, J.; Golis, T. Variability of phytochemical properties and content of bioactive compounds in Lonicera Caerulea L. var. Kamtschatica berries. J. Agric. Food Chem. 2013, 61, 12072-12084. 
30. Bassman, J.H. Ecosystem consequences of enhanced solar ultraviolet radiation: Secondary plant metabolites as mediators of multiple trophic interactions in terrestrial plant communities. Photochem. Photobiol. 2004, 79, 382-398. [CrossRef] [PubMed]

31. Wang, S.; Chen, C.-T.; Wang, C. The Influence of Light and Maturity on Fruit Quality and Flavonoid Content of Red Raspberries. Food Chem. 2009, 112, 676-684. [CrossRef]

32. Jurikova, T.; Rop, O.; Mlcek, J.; Sochor, J.; Balla, S.; Szekeres, L.; Hegedusova, A.; Hubalek, J.; Adam, V.; Kizek, R. Phenolic profile of edible honeysuckle berries (Genus Lonicera) and their biological effects. Molecules 2011, 17, 61-79. [CrossRef] [PubMed]

33. Zadernowski, R.; Naczk, M.; Nesterowicz, J. Phenolic acid profiles in some small berries. J. Agric. Food Chem. 2005, 53, 2118-2124. [CrossRef]

34. Deineka, V.I.; Sorokopudov, V.N.; Deineka, L.A.; Shaposhnik, E.I.; Kol'tsov, S.V. Anthocyans from fruit of some plants of the Caprifoliaceae family. Chem Nat Compd. 2005, 41, 162-164. [CrossRef]

35. Albert, A.; Sareedenchai, V.; Heller, W.; Seidlitz, H.K.; Zidorn, C. Temperature is the key to altitudinal variation of phenolics in Arnica montana L. Cv. ARBO. Oecologia 2009, 160, 1-8. [CrossRef]

36. Jusev, A.A.; Plekhanova, M.N. Samyje lučšije, 1st ed.; Vserossijskij Naučno-Issledovatel'skij Institut Rastenijevodstva I. Vavilova: Sankt Peterburg, Russia, 1997; pp. 120-122.

37. Costa, R.; Albergamo, A.; Pellizzeri, V.; Dugo, G. Phytochemical screening by LC-MS and LC-PDA of ethanolic extracts from the fruits of Kigelia africana (Lam.). Benth. Nat. Prod. Res. 2017, 31, 1397-1402. [CrossRef]

38. Cory, H.; Passarelli, S.; Szeto, J.; Tamez, M.; Mattei, J. The Role of Polyphenols in Human Health and Food Systems: A Mini-Review. Front. Nutr. 2018, 5, 87. [CrossRef]

39. Dinda, B.; Debnath, S.; Harigaya, Y. Naturally Occurring Iridoids. A Review, Part 1. Chem. Pharm. Bull. 2007, 55, 159-222. [CrossRef]

40. Sampaio-Santos, M.I.; Kaplan, M.A.C. Biosynthesis Significance of Iridoids in Chemosystematics. J. Brazil. Chem. Soc. 2001, 12, 144-153. [CrossRef]

41. Chaovanalikit, A.; Thompson, M.M.; Wrolstad, R.E. Characterization and quantification of anthocyanins and polyphenolics in blue honeysuckle (Lonicera caerulea L.). J. Agric. Food Chem. 2004, 52, 848-852. [CrossRef] [PubMed]

42. Kucharska, A.Z.; Sokół-Łętowska, A.; Oszmiański, J.; Piórecki, N.; Fecka, I. Iridoids, Phenolic Compounds and Antioxidant Activity of Edible Honeysuckle Berries (Lonicera Caerulea Var. Kamtschatica Sevast.). Molcules 2017, 22, 405. [CrossRef] [PubMed]

43. Gazdik, Z.; Krska, B.; Adam, V.; Saloun, J.; Pokorna, T.; Reznicek, V.; Horna, A.; Kizek, R. Electrochemical determination of the antioxidant potential of some less common fruit species. Sensors 2008, 8, 7564-7570. [CrossRef] [PubMed]

44. Halvorsen, B.L.; Carlsen, M.H.; Phillips, K.M.; Bøhn, S.K.; Holte, K.; Jacobs, D.R.; Blomhoff, R. Content of redox-active compounds (ie, antioxidants) in foods consumed in the United States. Am. J. Clin. Nutr. 2006, 84, 95-135. [CrossRef]

45. Skinner, M.; Hunter, D. (Eds.) Bioactives in Fruit: Health Benefits and Functional Foods; Wiley: Oxford, UK, 2013.

46. Szajdek, A.; Borowska, E.J. Bioactive compounds and health-promoting properties of berry fruits: A review. Plant Foods Hum. Nutr. 2008, 63, 147-156. [CrossRef] [PubMed]

47. Rop, O.; К̌ezníček, V.; Mlček, J.; Juríková, T.; Balík, J.; Sochor, J.; Kramářová, D. Antioxidant and radical oxygen species scavenging activities of 12 cultivars of blue honeysuckle fruit. Hortic. Sci. 2011, 38, 63-70. [CrossRef]

48. Usenik, V.; Fabčič, J.; Stampar, F. Sugars, organic acids, phenolic composition and antioxidant activity of sweet cherry (Prunus avium L.). Food Chem. 2008, 107, 185-192. [CrossRef]

49. Pacifico, S.; D'Abrosca, B.; Pascarella, M.; Letizia, M.; Uzzo, P.; Piscopo, V.; Fiorentino, A. Antioxidant efficacy of iridoid and phenylethanoid glycosides from the medicinal plant Teucrium chamaedris in cell-free systems. Bioorganic Med. Chem. 2009, 17, 6173-6179. [CrossRef]

50. Zhao, L.; Li, S.; Zhao, L.; Zhu, Y.; Hao, T. Antioxidant activities and major bioactive components of consecutive extracts from blue honeysuckle (Lonicera caerulea L.) cultivated in China. J. Food Biochem. 2015, 39, 653-662. [CrossRef] 
51. Zhao, H.; Wang, Z.; Ma, F.; Yang, X.; Cheng, C.; Yao, L. Protective effect of anthocyanin from Lonicera caerulea var. edulis on radiation-induced damage in mice. Int. J. Mol. Sci. 2012, 13, 11773-11782. [CrossRef] [PubMed]

52. Wang, Y.; Zhu, J.; Meng, X.; Liu, S.; Mu, J.; Ning, C. Comparison of polyphenol, anthocyanin and antioxidant capacity in four varieties of Lonicera caerulea berry extracts. Food Chem. 2016, 197, 522-529. [CrossRef] [PubMed]

53. Duthie, S. Berry phytochemicals, genomic stability and cancer: Evidence for chemoprotection at several stages in the carcinogenic process. Mol. Nutr. Food Res. 2007, 51, 665-674. [CrossRef] [PubMed]

54. Gordillo, G.; Fang, H.; Khanna, S.; Harper, J.; Phillips, G.; Sen, C.K. Oral administration of blueberry inhibits angiogenic tumor growth and enhances survival of mice with endothelial cell neoplasm. Antioxidant Redox Signal. 2009, 11, 47-58. [CrossRef] [PubMed]

55. Stull, A.J.; Cash, K.C.; Johnson, W.D.; Champagne, C.M.; Cefalu, W.T. Bioactives in blueberries improve insulin sensitivity in obese, insulin-resistant men and women. J. Nutr. 2010, 140, 1764-1768. [CrossRef] [PubMed]

56. Devareddy, L.; Hooshmand, S.; Collins, J.K.; Lucas, E.A.; Chai, S.C.; Arjmandi, B.H. Blueberry prevents bone loss in ovariectomized rat model of postmenopausal osteoporosis. J. Nutr. Biochem. 2008, 19, 694-699. [CrossRef]

57. Krikorian, R.; Shidler, M.D.; Nash, T.A.; Kalt, W.; Vinqvist-Tymchuk, M.R.; Shukitt-Hale, B.; Joseph, J.A. Blueberry supplementation improves memory in older adults. J. Agric. Food Chem. 2010, 58, 3996-4000. [CrossRef]

58. Raudsepp, P.; Anton, D.; Roasto, M.; Meremäe, K.; Pedastsaar, P.; Mäesaar, M.; Raal, A.; Laikoja, K.; Püssa, T. The antioxidative and antimicrobial properties of the blue honeysuckle (Lonicera caerulea L.), Siberian rhubarb (Rheum rhaponticum L.) and some other plants, compared to ascorbic acid and sodium nitrite. Food Control 2013, 31, 129-135. [CrossRef]

59. Palíková, I.; Heinrich, J.; Bednár, P.; Marhol, P.; Kren, V.; Cvak, L.; Valentová, K.; Růzicka, F.; Holá, V.; Kolár, M.; et al. Constituents and antimicrobial properties of blue honeysuckle: A novel source for phenolic antioxidants. J. Agric. Food Chem. 2008, 56, 11883-11889. [CrossRef]

60. Jones, Q.R.D.; Warford, J.; Rupasinghe, H.P.V.; Robertson, G.S. Target-based selection of flavonoids for neurodegenerative disorders. Trends Pharmacol. Sci. 2012, 33, 602-610. [CrossRef]

61. Whyte, A.R.; Cheng, N.; Fromentin, E.; Williams, C.M. A randomized, double-blinded, placebo-controlled study to compare the safety and efficacy of low dose enhanced wild blueberry powder and wild blueberry extract (ThinkBlue ${ }^{\mathrm{TM}}$ ) in maintenance of episodic and working memory in older adults. Nutrients 2018, 10, 660. [CrossRef] [PubMed]

62. Bell, L.; Williams, C.M. A pilot dose-response study of the acute effects of haskap berry extract (Lonicera caerulea L.) on cognition, mood, and blood pressure in older adults. Eur. J. Nutr. 2019, 58, 3325-3334. [CrossRef] [PubMed]

63. Rodriguez-Mateos, A.; Rendeiro, C.; Bergillos-Meca, T.; Tabatabaee, S.; George, T.W.; Heiss, C.; Spencer, J.P. Intake and time dependence of blueberry flavonoid-induced improvements in vascular function: A randomized, controlled, double-blind, crossover intervention study with mechanistic insights into biological activity. Am. J. Clin. Nutr. 2013, 98, 1179-1191. [CrossRef] [PubMed]

64. Bell, L.; Lamport, D.J.; Butler, L.T.; Williams, C.M. A study of glycaemic effects following acute anthocyanin-rich blueberry supplementation in healthy young adults. Food Funct. 2017, 8, 3104-3110. [CrossRef] [PubMed]

65. Aruoma, O.I. Free radicals, oxidative stress, and antioxidants in human health and disease. J. Am. Oil Chem. Soc. 1998, 75, 199-212. [CrossRef]

66. Svobodová, A.; Zdařilová, A.; Vostálová, J. Lonicera caerulea and Vaccinium myrtillus fruit polyphenols protect HaCaT keratinocytes against UVB-induced phototoxic stress and DNA damage. J. Dermatol. Sci. 2009, 56, 196-204. [CrossRef]

67. Cho, N.H.; Shaw, J.E.; Karuranga, S.; Huang, Y.; da Rocha Fernandes, J.D.; Ohlrogge, A.W.; Malanda, B. IDF Diabetes Atlas: Global estimates of diabetes prevalence for 2017 and projections for 2045. Diabetes Res. Clin. Pr. 2018, 138, 271-281. [CrossRef]

68. Sami, W.; Ansari, T.; Butt, N.S.; Hamid, M.R.A. Effect of diet on type 2 diabetes mellitus: A review. Int. J. Health Sci. (Qassim) 2017, 11, 65-71. 
69. Sharma, A.; Kim, J.W.; Ku, S.-K.; Choi, J.-S.; Lee, H.-J. Anti-diabetic effects of blue honeyberry on high-fed-diet-induced type II diabetic mouse. Nutr. Res. Pr. 2019, 13, 367-376. [CrossRef]

70. Mehta, J.; Rasouli, N.; Sinha, A.; Molavi, B. Oxidative Stress in Diabetes: A mechanistic overview of its effects on atherogenesis and myocardial dysfunction. Int. J. Biochem. Cell Biol. 2006, 38, 794-803. [CrossRef]

71. Valko, M.; Rhodes, C.J.; Moncol, J.; Izakovic, M.; Mazur, M. Free radicals, metals and antioxidants in oxidative stress-induced cancer. Chem. Interactions 2006, 160, 1-40. [CrossRef] [PubMed]

72. Prescott, S.L. Early-Life Environmental determinants of allergic diseases and the wider pandemic of inflammatory noncommunicable diseases. J. Allergy Clin. Immunol. 2013, 131, 23-30. [CrossRef] [PubMed]

73. Ford, E.S.; Giles, W.H.; Dietz, W.H. Prevalence of the metabolic syndrome among US adults: Findings from the Third National Health and Nutrition Examination Survey. JAMA 2002, 287, 356-359. [CrossRef] [PubMed]

74. Rupasinghe, H.P.V.; Boehm, M.M.A.; Sekhon-Loodu, S.; Parmar, I.; Bors, B.; Jamieson, A.R. Anti-inflammatory activity of haskap cultivars is polyphenols-dependent. Biomolecules 2015, 5, 1079-1098. [CrossRef] [PubMed]

75. Zdarilová, A.; Svobodová, A.; Chytilová, K.; Simánek, V.; Ulrichová, J. Polyphenolic fraction of Lonicera caerulea 1 . fruits reduces oxidative stress and inflammatory markers induced by lipopolysaccharide in gingival fibroblasts. Food Chem. Toxicol. 2010, 48, 1555-1561. [CrossRef] [PubMed]

76. Qin, J.; Li, Y.; Cai, Z.; Li, S.; Zhu, J.; Zhang, F.; Liang, S.; Zhang, W.; Guan, Y.; Shen, D.; et al. A metagenome-wide association study of gut microbiota in type 2 diabetes. Nature 2012, 490, 55-60. [CrossRef] [PubMed]

77. Vrieze, A.; Van Nood, E.; Holleman, F.; Salojärvi, J.; Kootte, R.S.; Bartelsman, J.F.W.M.; Dallinga-Thie, G.M.; Ackermans, M.T.; Serlie, M.J.; Oozeer, R.; et al. Transfer of intestinal microbiota from lean donors increases insulin sensitivity in individuals with metabolic syndrome. Gastroenterology 2012, 143, 913-916.e7. [CrossRef]

78. Wu, S.; Hu, R.; Nakano, H.; Chen, K.; Liu, M.; He, X.; Zhang, H.; He, J.; Hou, D.-X. Modulation of gut microbiota by Lonicera caerulea L. berry polyphenols in a mouse model of fatty liver induced by high fat diet. Molecules 2018, 23, 3213. [CrossRef]

79. Kessoku, T.; Imajo, K.; Honda, Y.; Kato, T.; Ogawa, Y.; Tomeno, W.; Higurashi, T.; Yoneda, M.; Shimakawa, M.; Tanaka, Y.; et al. Characteristics of Fecal Microbiota in Japanese Patients with Nonalcoholic Fatty Liver Disease: A Connection among Gut-Permeability, Endotoxin and NAFLD. Gastroenterology 2017, 152. [CrossRef]

80. Del Chierico, F.; Nobili, V.; Vernocchi, P.; Russo, A.; De Stefanis, C.; Gnani, D.; Furlanello, C.; Zandonà, A.; Paci, P.; Capuani, G.; et al. Gut microbiota profiling of pediatric nonalcoholic fatty liver disease and obese patients unveiled by an integrated meta-omics-based approach. Hepatology 2017, 65, 451-464. [CrossRef]

81. Jin, X.-H.; Ohgami, K.; Shiratori, K.; Suzuki, Y.; Koyama, Y.; Yoshida, K.; Ilieva, I.; Tanaka, T.; Onoe, K.; Ohno, S. Effects of blue honeysuckle (Lonicera caerulea L.) extract on lipopolysaccharide-induced inflammation in vitro and in vivo. Exp. Eye Res. 2006, 82, 860-867. [CrossRef] [PubMed]

82. Jurgoński, A.; Juśkiewicz, J.; Zduńczyk, Z. An anthocyanin-rich extract from Kamchatka honeysuckle increases enzymatic activity within the gut and ameliorates abnormal lipid and glucose metabolism in rats. Nutrition 2013, 29, 898-902. [CrossRef] [PubMed]

83. Palíková, I.; Valentová, K.; Oborná, I.; Ulrichová, J. Protectivity of Blue Honeysuckle Extract against Oxidative Human Endothelial Cells and Rat Hepatocyte Damage. J. Agric. Food Chem. 2009, 57, 6584-6589. [CrossRef]

84. Liu, M.; Tan, J.; He, Z.; He, X.; Hou, D.-X.; He, J.; Wu, S. inhibitory effect of blue honeysuckle extract on high-fat-diet-induced fatty liver in mice. Anim. Nutr. 2018, 4, 288-293. [CrossRef] [PubMed]

85. Technical report on the notification of berries of Lonicera caerulea L. as a traditional food from a third country pursuant to Article 14 of Regulation (EU) 2015/2283. Available online: https://www.efsa.europa.eu/ en/supporting/pub/en-1442 (accessed on 4 December 2019).

86. Senica, M.; Stampar, F.; Mikulic-Petkovsek, M. Different extraction processes affect the metabolites in blue honeysuckle (Lonicera caerulea L. subsp. edulis) Food Products. Turk. J. Agric. For. 2019, 43, 576-585. [CrossRef]

(C) 2020 by the authors. Licensee MDPI, Basel, Switzerland. This article is an open access article distributed under the terms and conditions of the Creative Commons Attribution (CC BY) license (http://creativecommons.org/licenses/by/4.0/). 